Ya. Leonov

Ya. Leonov,

PhD (Economics), Associate Professor, ORCID 0000-0001-8837-5744, e-mail: leonov.yaroslav.2017@gmail.com, Kharkiv State Academy of Physical Culture

\title{
MODERN APPROACH TO SPORTS INDUSTRY MANAGEMENT UNDER UNCERTAINTY
}

Formulation of scientific problem and its significance. The crisis caused by the pandemic, which affects the entire world society, has revealed the inability of government agencies to respond quickly to overcome the consequences of this phenomenon. Dynamic changes that occur under the influence of socio-political, economic, energy and environmental factors, increase uncertainty, increase risks, have a significant impact on the development of economic sectors and society as a whole. The world economy is in an unstable state, the way out of which can provide a new wave of the new world, which will be a catalyst for long-term growth and development.

Leading countries, taking on modern challenges, take an active position in overcoming the crisis: implement stabilization measures and create conditions for sustainable economic development in the long run. Others, following the actions of leaders, use effective mechanisms and tools in their management practices.

Transformation processes taking place in Ukraine cause significant changes in all spheres of public life, differently affect the functioning of organizations, sectors of the economy (energy, industry, agriculture, sports industry), which introduce new principles, approaches, rules to improve the efficiency of their activities. The situation in the sports industry remains difficult: sports infrastructure does not meet modern standards, low wages, insufficiently qualified staff, difficult conditions for attracting investment, and so on. The relevance of the study is explained by the requirements of the need to improve the organizational support for the development of the sports industry. This fact necessitates the solution of the problem of progressive innovative development of the sports industry in conditions of uncertainty on the basis of the modern mechanism of state regulation in the system "state - community science - business" and the development of socially oriented economic policy.

Analysis of research and publications. The problems of implementation of a modern management system of socio-economic development of territories, sectors of the economy (energy, industry, etc.) at the state and regional levels, is reflected in the works of famous domestic and foreign scientists: V. Geets [1], A. Dvigun [2], M. Porter [3], A. Umland [4] and others. However, the issue of effective management of the sports industry in conditions of uncertainty and ensuring the conditions of strategic development remains unresolved.
The purpose of the study is to explore modern approaches to the management of the sports industry aimed at increasing the competitiveness, efficiency and sustainable development of the sports industry in conditions of uncertainty.

Presentation of the main material and substantiation of the obtained research results. Global changes taking place in the world pose various challenges to modern society, among which the most important is the awareness and formation of a new technological way of life, which will significantly affect life, working conditions, economy, communications. In scale, this phenomenon can be considered the fourth industrial revolution, which has no analogue in the previous history of mankind. The introduction of blockchain technologies, artificial intelligence, robotics, nano-, biotechnology, the Internet of Things, energy storage and conservation requires a rethinking of the system of society management at the state, territory and organizational levels.

The introduction of the European model of management of socio-economic development in Ukraine is associated with complex systemic transformations, in which a new quality society is formed, the level of business activity and political responsibility of citizens increases, human rights and freedoms are ensured. These changes in the structure and content of civil society inevitably lead to changes in the form and essence of public policy in the system of state, territorial and sectoral government. Exacerbation of competition, significant technological changes, increasing the impact of human capital on the main factors of economic development, the contradiction between the growing needs of society in a healthy lifestyle, sports and insignificant opportunities to provide quality sports and medical services are modern challenges for the state. Overcoming them requires the development and implementation of an effective management system, using balanced methods of direct and indirect management, program-targeted approach, taking into account the culture, traditions, mentality, ideology of modern society.

The process of evolution of the socio-economic system contributes to the gradual transformation of public administration into modern models of regulation and development of society. The classical theory of management in the public sector was implemented in practice through a model of administration using direct action methods. Methods of administrative management are 
orders (requirements, prohibitions, etc.) that oblige to act in a certain way, reducing publicity, and through which public authorities directly interfere in economic processes (public procurement, subsidies, subventions, grants, licensing and quotas, fixed pricing). Neoclassical theory of management - a model of management, in the center of which is already a person, not an organizational structure $[2 ; 3 ; 4]$.

Modern theory - a model of new governance focused on the effective functioning of the entire system of political institutions through the introduction of strategic management, reducing the public sector, improving the quality of public services, forming a style of "effective" governance, i.e. special attention is paid to communication.

Thus, the trends of society in the context of globalization and decentralization of the economy, expanding market powers are focused on the use of modern management and administration of the economy, based on a system of direct and indirect action (principles, methods, techniques, rules and means of state influence on social). economic development of the country). It should be noted that the methods of indirect action are quite effectively used in the EU, USA, Japan, Singapore and others. It is projected that with the construction of a legal economically developed and stable state, they will also spread in the activities of Ukrainian institutions. [6].

Methods of indirect action include legal and economic. Legal methods - a system of laws and legislative acts that regulate the activities of market participants and determine the legal space. The essence of legal methods of public administration is the legal influence on the socio-legal sphere and its individual elements in the process of regulating public relations, the main participant of which is the state power.

Economic methods of state regulation of the economy are associated with the creation of financial or material incentives that can long-term influence the behavior and economic interests of market participants by developing and implementing optimal tax, budget, monetary, investment, innovation, depreciation, structural, information and economic policy. The effectiveness of socio-economic reforms is determined by the nature of the state's influence on the development of socio-economic processes.

The crisis situation in the sports industry significantly depends on the effectiveness of public administration. State and territorial regulation of the sports industry is based on methods of direct action, where there is only state responsibility for the physical condition of man and, accordingly, formed standard types and forms of sports and health practices, unreasonably used (copied) global management technologies without regard to cultural traditions, mentality, which are inherent in Ukrainian society. In addition, in the process of decentralization, some functions related to the development of the sports industry are transferred to the local level, but the financing of these functions is not always in full. This situation does not contribute to the provision of quality sports and health services, encouraging the population to physical activity, physical culture and sports, which negatively affects human health [6].

Ukraine's technological lag behind developed countries is growing, the structure of Ukraine's economy remains distorted, and its dependence on fluctuations in world market conditions is growing. Scientific and technical, innovative potential, human capital of the country continues to degrade, the wave of inflation is growing. It should be noted the positive dynamics: in 2019, compared to 2018, Ukraine rose by 13 positions in the ranking of economic freedom and took 134th place out of 180 countries. This is evidenced by the data of the Index of Economic Freedom, which was compiled the Heritage Foundation. It is also noted that Ukraine is in the category of "mostly unfree" countries and ranks last 45 th in the European region. The overall score of Ukraine (54.9) is much lower than the average of regional and world indicators [8]. The ranking is based on a comprehensive study of the state of reforms in each country on 10 key indicators and is an important indicator for investors in making investment decisions. For example, the indicator of doing business in 2020 shows that 115 countries out of 190 participants in the global ranking are actively reforming and simplifying the national business environment. In the ranking of "Doing Business" in the period 2013-2019, Ukraine. has a positive dynamics. Thus, in 2013, Ukraine ranked 137th in the ranking of investment attractiveness of doing business, and in 2020 ranked 64th among 190 countries.

It should be noted that Ukraine is not one of the leaders of reforms. This is influenced by: inefficiency of the state system of government and socio-economic policy, a significant decrease in people's trust in state institutions. However, ratings are actually limited in use, as "place among others" does not indicate the path of development, and even the countries that form the "top three" are not a benchmark. The problem is rather not to catch up with the "first", but to implement its own model of sustainable long-term development.

With the introduction of modern standards of management and resource provision of the sports industry there are certain problems of the socio-economic situation of Ukrainian society: demographic crisis, devaluation of traditional moral values, deteriorating health and lack of motivation to increase physical activity. That is, there is a need to ensure the development of the sports industry in the system "state - community - science business" and the development of socially responsible economic policy.

The problem of developing social responsibility of business in Ukraine at the present stage is relevant and of paramount importance. State support is necessary for the importance of ethical and socially responsible behavior of organizations, increasing their prestige. The country should create incentives for social responsibility, provide legal conditions for social investment, flexible tax policy for charitable organizations, give 
them priority when obtaining licenses, promote their experience, and so on.

Improving the management system of the sports industry in the face of dynamic changes requires the introduction of modern tools, methods, models, technologies that meet the needs of the population, taking into account the effective use of internal resources of the sports industry. In the context of globalization and decentralization of the economy, the question of applying such management methods as persuasion, stimulation and encouragement becomes relevant. These methods are complementary and interconnected, have an objective character, there is a dialectical unity between them, the degree of their use is determined by the level of development of social relations $[7 ; 8]$.

So, for example, encouragement - a way of influence that through interest, consciousness directs the will of people to carry out useful, in terms of encouraging, things. Encouraging influence promotes the emergence of interest in the implementation of certain cases, obtaining material, moral and other approval.

Persuasion is a special means of legal influence. It is that the subjects of public administration comply with certain requirements as a result of their internal recognition, and not through blind obedience to the dictates of power. The main forms of persuasion carried out in public administration are: organization of state and public events aimed at solving specific tasks (accounting, control, adoption of necessary documents, conferences, seminars, round tables); education (economic, legal, moral, etc.) and personal example; explanation of public administration tasks (orally or through the media); instructing persons of the subordinate apparatus and the public on the issues of the most effective performance of the set tasks.

With the reduction of state influence on political, economic and social processes, there is a need to use new forms of government in the public sector. Old management methods based on the widespread use of power, commands, orders, strict administration should be replaced by motivating the effectiveness of public services, the priority of market-based instruments of economic regulation, innovative program-targeted strategies to improve the quality of life $[4 ; 8]$. That is, the modern way of governing society involves, first of all, a radical change in the format of relations between government and man, creating stimulating organizational conditions for the development of the sports industry in the process of transformation, adequate to Ukrainian realities, traditions, culture and best world practices.

Public policy in many countries is based on the understanding that the sports industry has great potential to promote, on the one hand, sustainable economic development and job creation, through a positive impact on social integration, education, training, health care, social security. On the other hand, building an effective management mechanism to ensure the strategic development of the sports industry, the formation of a healthy, athletic, competitive person and the nation as a whole.

The results of a study on the level of physical activity of people in the European Union show that the indicator of the number of people engaged in various types of physical activity (aged 15 and older) is at 14\%. It was found that in most European countries, the largest number of physically active people belongs to the group with the highest income. Note that at this stage, in most EU countries, the main funding for sports is provided by local governments, but the population has increased its spending on sports by almost $25 \%$ in 2019 compared to 2018 [7; 9].

This is a trend for other countries: the livelihood of the physically active population of Canada in 2019 decreased by $5 \%$ compared to a minimum of $72 \%$, of which $90 \%$ of the highest income group. In the United States, the number of physically active people (aged 18 and older) was $51 \%$ in 2019 , which is $3 \%$ less than in 2018, while the population with the highest income will be $59 \%$. In Australia, the number of physically active population in 2019 will be $60 \%$, which is $5 \%$ lower than last year $[5 ; 7]$.

Thus, there is a general trend in the world to reduce the number of physically active people. To solve this problem, the European Commission defines physical activity, which promotes good health, as the basis of its sports activities. The organization of sports in Europe on the basis of non-profit clubs strengthens active citizenship, so there are key problems for non-profit sports organizations, in addition, it is believed that sports equal opportunities and open access to sports infrastructure can be guaranteed only through active public participation. At the same time, sustainable funding of sports, and especially sports for all, is one of the EU's priorities.

Providing public and private funding on a more reliable basis focuses on three main areas: changes in the regulatory framework (competition law, state aid rules, the state of the domestic market, tax policy); involvement of financial and investment partners, stakeholders, investment organizations, EU funds under targeted programs; exchange of best practices between different organizations and EU countries.

Conclusions and prospects for further research. Ukraine's transition to European standards of public relations, the development of a democratic state governed by the rule of law require an effective, flexible, adapted to new challenges system of government, focused on human capital development, which will accelerate innovation development. Improving the efficiency of cooperation in the system "state - community - science - business" and building a socially responsible economic policy, improving the quality of the national management system of sports is one of the main conditions for sustainable socio-economic development of the country as a whole, as well as a major factor in improving the quality of human life. 


\section{Literature}

1. Геєць В. М. Феномен нестабільності - виклик економічному розвитку: монографія / НАН України, Держ. установа "Ін-т економіки та прогнозування НАН України". Київ : Академперіодика, 2020. 454 с. 2. Двігун А. Реформа адміністративно-територіального устрою в Україні як чинник зміцнення територіального розвитку. Review of transport economics and management. 2020. №3(19). C. 213-220. doi: https://doi.org/10.15802/rtem.v0i3(19).211180. 3. Портер М. Международная конкуренция. Конкурентные преимущества стран: пер. с англ. Москва: Альпина Паблишер, 2018. 952 с. 4. Умланд А. Чотири геополітичні виміри децентралізації України. Дзеркало тижня. 2019. 11 січ. URL: https:/dt.ua/internal/chotirigeopolitichni-vimiri - decentralizaciyi - ukrayini-299352_. html.5. Global Health Observatory data repository. Database World Health Organization. URL: http://apps.who.int/gho/data/node.main.A893?lang=en.

6. Публічне управління та адміністрування в умовах інформаційного суспільства: вітчизняний і зарубіжний досвід: монографія / За заг. ред. С. Чернова, В. Воронкової, В. Банаха, О. Сосніна, П. Жукаускаса, Й. Р. Андрюкайтене. Запоріжжя: ЗДІА, 2017. 602 с. 7. Country Rankings. 2020 Index of Economic Freedom. URL: https: //www.heritage.org/index/ranking?version=507. 8. Database. Database European Comission. URL: http://ec. europa.eu/eurostat/data/database. 9. Про затвердження Стратегії розвитку фізичної культури і спорту на період до 2028 року: Постанова Кабінету Міністрів України від 4 листопада 2020 р. № 1089. URL: https://zakon.rada.gov.ua/laws/show/1089-2020-п\#Text.

\section{References}

1. Heiets, V. M. (2020). The phenomenon of instability - a challenge to economic development. Kyiv, Akademperiodyka [in Ukrainian].

2. Dvihun, A. (2020). Reform of the administrativeterritorial system in Ukraine as a factor in strengthening territorial development. Review of transport economics and management, 3 (19), pp. 213-220. doi: https: //doi.org/10.15802/rtem.v0i3(19).211180 [in Ukrainian].

3. Porter, M. (2018). International Competition. Competitive Advantages of Countries. Trans. from english. Moscow, Alpina Publisher [in Russian].

4. Umland, A. (2019). Chotyry heopolitychni vymiry detsentralizatsii Ukrainy [Four geopolitical dimensions of decentralization of Ukraine]. Dzerkalo tyzhnia - Mirror of the week, 11 Jan. Retrieved from https://dt.ua/internal/chotiri-geopolitichni-vimiri-decentralizaciyi-ukrayini299352_html [in Ukrainian].

5. Global Health Observatory data repository. Database World Health Organization. Retrieved from http://apps.who.int/gho/data/node.main.A893?lang=en.

6. Chernov, S., Voronkova, V., Banakh, V. et al. (Eds.). (2017). Public administration and administration in the information society: domestic and foreign experience. Zaporizhzhia, ZSEA [in Ukrainian]

7. Country Rankings. 2020 Index of Economic Freedom. Retrieved from https://www.heritage.org/index/ranking?version $=507$.
8. Database. Database European Comission. Retrieved from http://ec.europa.eu/eurostat/data/database.

9. On approval of the Strategy for the development of physical culture and sports for the period up to 2028: Resolution of the Cabinet of Ministers of Ukraine of November 4, 2020 № 1089. Retrieved from https://zakon.rada. gov.ua/laws/show/1089 -2020-n \# Text [in Ukrainian].

Леонов Я. В. Сучасний підхід до управління спортивною індустрісю в умовах невизначеності

У статті розглянуто організаційні умови функціонування спортивної індустрії, запропоновано напрями забезпечення стратегічного розвитку спортивної індустрії в умовах невизначеності. Проаналізовано можливість впровадження європейської моделі управління соціально-економічним розвитком в Україні, зроблено висновок: це пов'язано зі складними системними перетвореннями, в яких формується суспільство нової якості, підвищується рівень ділової активності та політичної відповідальності громадян, забезпечуються права і свободи людини. Ці зміни у структурі та змісті громадянського суспільства неминуче детермінують зміни у формі та сутності державної політики в системі державного, територіального та секторального управління. Проблема розвитку соціальної відповідальності бізнесу в Україні на сучасному етапі $є$ актуальною й має першочергове значення. Тому підтримка держави необхідна для важливості етичної та соціально відповідальної поведінки організацій, підвищення їхньої престижності. Впровадження системи сучасного управління спортивною індустрією, використання кращих європейських практик управління дозволять підвищити конкурентоспроможність, ефективність та забезпечити сталий розвиток спортивної індустрії в умовах невизначеності.

Підвищення ефективності взаємодії у системі «держава - громада - наука - бізнес» та розбудови соціально відповідальної економічної політики, підвищення якості національної системи управління спортивною індустрією є однією з головних умов забезпечення сталого соціально-економічного розвитку країни в цілому, а також основним чинником покращення якості життя людини.

Ключові слова: стратегічний розвиток, регулювання, методи управління, людський капітал, спортивна індустрія, рейтингові оцінки, соціальна відповідальність бізнесу.

Leonov Ya. Modern Approach to Sports Industry Management under Uncertainty

The article considers the organizational conditions for the functioning of the sports industry, suggests ways to ensure the strategic development of the sports industry in conditions of uncertainty. The possibility of implementing the European model of socio-economic development management in Ukraine is analyzed, it is concluded that it is connected with complex systemic transformations in which a new quality society is formed, the level of business activity and political responsibility of citizens increases, human rights and freedoms are ensured. These changes in the structure and 
content of civil society inevitably determine changes in the form and essence of public policy in the system of state, territorial and sectoral government. The problem of developing social responsibility of business in Ukraine at the present stage is relevant and of paramount importance. Therefore, state support is necessary for the importance of ethical and socially responsible behavior of organizations, increasing their prestige. The introduction of a system of modern management of the sports industry, the use of best European management practices will increase competitiveness, efficiency and ensure the sustainable development of the sports industry in conditions of uncertainty. Improving the efficiency of interaction in the system "state - community - science business" and building a socially responsible economic policy, improving the quality of the national management system of the sports industry is one of the main conditions for sustainable socio-economic development of the country as a whole. man.

Keywords: strategic development, regulation, management methods, human capital, sports industry, rating assessments, social responsibility of business.

Леонов Я. В. Современный подход к управлению спортивной индустрией в условиях неопределенности

В статье рассмотрены организационные условия функционирования спортивной индустрии, предложены направления обеспечения стратегического развития спортивной индустрии в условиях неопределенности. Проанализирована возможность внедрения европейской модели управления социально-экономи- ческим развитием в Украине, сделан вывод: это связано со сложными системными преобразованиями, в которых формируется общество нового качества, повышается уровень деловой активности и политической ответственности граждан, обеспечиваются права и свободы человека. Эти изменения в структуре и содержании гражданского общества неизбежно детерминируют изменения в форме и сущности государственной политики в системе государственного, территориального и секторального управления. Проблема развития социальной ответственности бизнеса в Украине на современном этапе является актуальной и имеет первостепенное значение. Поэтому поддержка государства необходима для важности этической и социально ответственного поведения организаций, повышения их престижности. Внедрение системы современного управления спортивной индустрией, использование лучших европейских практик управления позволят повысить конкурентоспособность, эффективность и устойчивое развитие спортивной индустрии в условиях неопределенности. Повышение эффективности взаимодействия в системе «государство - общество наука - бизнес» и развития социально ответственной экономической политики, повышение качества национальной системы управления спортивной индустрией является одним из главных условий обеспечения устойчивого социально-экономического развития страны в целом, а также основным фактором улучшения качества жизни человека.

Ключевые слова: стратегическое развитие, регулирование, методы управления, человеческий капитал, спортивная индустрия, рейтинговые оценки, социальная ответственность бизнеса.

Received by the editors: 02.10 .2020 and final form 29.12.2020 